\title{
Öğretmenlerin Örgütsel Adalet Algıları ile Örgütsel Vatandaşlık Davranışları Arasındaki ilişki'
}

\author{
Aykut GÜNES ${ }^{*}$ \\ Rüyam KÜÇÜKSÜLEYMANOĞLU**
}

\begin{abstract}
Öz: İşgörenlerin örgütlerine ilişkin adalet algısı olarak tanımlanan örgütsel adalet, örgüt çıktılarının niteliğini etkilemektedir. Örgütünü adil bulan işgörenler, rol davranışlarından fazlasını sergileme eğilimindedirler. Gönüllülüğe dayanan örgütsel vatandaşlık davranışı, sosyal mekanizmayı güçlendirerek örgütsel gelişime katkı sağlamaktadır. Bireysel performans ve örgütsel kaynakların koordinasyonunu etkileyen bu iki kavram arasındaki ilişkinin saptanmasıyla eğitim örgütlerine katkı sağlanacağı düşünülmektedir. Araştırmada öğretmenlerin örgütsel adalet algıları ile örgütsel vatandaşlık davranışları arasındaki ilişkiyi ortaya koymak amaçlanmıştır. İlişkisel tarama modelinde yapılan araştırmanın örneklemi, İstanbul ili Pendik ilçesinde 36 farklı okulda çalışan 721 öğretmenden oluşmuştur. Veriler; kişisel bilgi formu, "Örgütsel Adalet Ölçeği" ve "Örgütsel Vatandaşlık Davranışı Ölçeği" ile toplanmış; Pearson korelasyon analizi ve regresyon analiziyle çözümlenmiştir. Araştırma sonucunda örgütsel adalet ve alt boyutları ile örgütsel vatandaşlık davranışları arasında olumlu, zayıf düzeyde bir ilişkinin olduğu saptanmıştır. Örgütsel vatandaşlık ve alt boyutları ile örgütsel adalet arasında olumlu, zayıf düzeyde ilişki olduğu bulunmuştur. Örgütsel adalet ve alt boyutlarının örgütsel vatandaşlık davranışlarını anlamlı düzeyde açıkladığı görülmüştür.
\end{abstract}

Anahtar Sözcükler: Örgütsel Adalet, Örgütsel Vatandaşlık, Eğitim Yönetimi, Örgütsel Davranış

\section{The Correlation Between Teachers' Organizational Justice Perception and Their Organizational Citizenship Behaviours}

\begin{abstract}
Organizational justice, which is defined as employees' justice perceptions towards their organization, affects the quality of output of organizations. Employees finding the organization fair tend to perform beyond role behaviours. Organizational citizenship behaviours based on willingness contribute to organizational development by strengthening the social mechanism. Determining the correlation between these two concepts that affect personal performance and coordination of organizational resources is thought to contribute to educational organizations. The research aimed at determining the correlation between teachers' organizational justice perceptions and organizational citizenship behaviours. The sample of the research, which is based on a correlational survey model, was 721 teachers working at 36 different public schools in Pendik, Istanbul. Data were collected with a personal information form, the "Organizational Justice Scale" and the "Organizational Citizenship Behaviour Scale". The data were analyzed with Pearson correlation and regression analysis. At the end of the research a weak, positive correlation of organizational justice and its sub-dimensions with organizational citizenship behaviours was found. A weak positive correlation of organizational citizenship and its sub-dimensions with organizational justice was found. It was found that organizational justice and its sub-dimensions predicted organizational citizenship behaviours significantly.
\end{abstract}

Keywords: Organizational Justice, Organizational Citizenship, Educational Administration, Organizational Behaviour

${ }^{1}$ Bu çalışma, Bursa Uludağ Üniversitesi Eğitim Bilimleri Enstitüsünde yürütülen yüksek lisans tezinin verilerinin bir kısmı kullanılarak hazırlanmıştır.

* Milli Eğitim Bakanlığı, Türkçe Öğretmeni, İstanbul, Türkiye, e-posta: gnsaykt@gmail.com, ORCID: https://orcid.org/0000-0002-7865-6099

** Bursa Uludağ Üniversitesi, Eğitim Fakültesi, Eğitim Bilimleri Bölümü, Bursa, Türkiye, e-posta: ruyamk@uludag.edu.tr, ORCID: https://orcid.org/0000-0003-3540-2117
} 
Bireyler, zamanlarının büyük bir bölümünü çalışma ortamlarında geçirmektedir. Sosyal etkileşimle gelişen olay ve durumların adil olup olmaması işgören davranışlarının niteliğine etki etmektedir. İşyerindeki adaletin rolünü açılayan örgütsel adalet kavramı, işgörenlerin örgüt içerisinde yetkiyi elinde bulunduranların kendilerine ne kadar adaletli davrandıkları ile ilgili algılarıdır (Whitman, Caleo, Carpenter, Horner ve Bernerth, 2012). Adams'ın (1965) geliştirdiği Eşitlik Kuramı'na göre işgörenler girdilerini (katkıda bulunulan her şey) çıktılarına (elde edilen her şey) oranlamaktadırlar ve bu oranları diğer işgörenlerin girdi/çıktı oranlarıyla karşılaştırmaktadırlar. Kıyaslamalarda eşitsizlik gören işgörenler bazı olumsuz tepkiler verirken, iş ve işlemlerin adil olduğunu düşündüklerinde daha üretken ve memnun olmaktadırlar. Benzer şekilde Crosby'nin (1976) "Göreli Yoksunluk Kuramı" ve Leventhal'ın (1976) "Adalet Yarg1 Kuramı" da bireylerin emek/ödül orantısının adilliğine odaklanmıştır. Thibaut ve Walker (1975) tarafından ileri sürülen Süreç Kontrolü Kuramı'na göre örgütsel prosedürlerin tutarlı, ahlaki ve etik kurallara uygun olması durumunda verilen kararların olumlu ya da olumsuz olması durumuna bakılmaksızın adil olarak algılanmaktadır. Leventhal, Karuza ve Fry'ın (1980) "Dağıtım Tercihi Kuramı" ise karar mekanizmasının bireylerin bilgi almasına olanak sağlayan, doğru bilgilere dayanan, ön yargıların oluşmasını engelleyen prosedürler ile çalışanların harekete geçirilebileceğini açıklamaktadır. Bu bağlamda örgütsel adalet, işgörenlerin örgütleri hakkındaki düşüncelerini ve bu düşünceleri doğrultusunda örgütlerine karşı nasıl bir tutum ve davranış içine gireceklerini belirlemede oldukça önemlidir (Alanoğlu ve Demirtaş, 2019; Berber, 2010; Cohen-Charash ve Spector, 2001, s. 278-279; İçerli, 2010).

Greenberg (1990) örgütsel adaleti dağıtımsal, işlemsel ve etkileşimsel adalet olmak üzere üç boyutta incelemiştir. Dağıtımsal adalet; işgörene verilen sorumluluk, ödül, terfi gibi kazanımların dağıtımına ilişkin adalet algısıdır (Moorman, 1991). İşlemsel adalet; kazanımları belirlemeye yönelik karar verme, planlama ve bunların yürütülmesinde dürüst ve adil davranılıp davranılmadığı ile ilgilidir (Folger ve Crapanzano, 1998). Etkileşimsel adalet ise uygulamalar esnasında görülen kişilerarası etkileşime ilişkin adalet algısıdır.

İşgörenler, algıladıkları örgütsel adalet düzeyine göre bilişsel ve davranışsal düzeyde çeşitli tepkiler ortaya koyabilmektedirler (Bal, 2014). Kendilerine adil davranıldığını düşünen işgörenlerin çalışma isteklerinin ve sergiledikleri örgütsel vatandaşlık davranışı sıklığının arttığı görülmektedir (Atalay, 2005; Berber, 2010; Beugré, 2002; Greenberg, 1990; Moorman, 1991; Organ, 1990; Polat ve Celep, 2008; Sezgin, 2005; Söyük, 2007; Uslu, 2011). Böylelikle örgüt içinde aidiyet duygusu gelişmekte ve örgütsel gelişim için zorunlulukların ötesine geçilerek fazladan çaba gösterilmektedir. Bu bakımdan örgütsel adalet, işgörenlerin kişisel doyumunu sağlama ve örgütün etkili bir biçimde işlevlerini yerine getirebilmesi için bir gerekliliktir (Greenberg, 1990).

Örgütlerin sürekli değişen koşullar altında varlıklarını sürdürebilmeleri için, formal iş tanımlarının çizdiği sınırların ötesine geçen, örgütsel etkililiğe ve gelişmeye katkı sağlamaya istekli işgörenlere ihtiyacı vardır (Sezgin, 2005, s.313). Bu ihtiyaca dönük, tanımlanmış rol davranışlarının ötesinde, gönüllülük ve fazladan gayret içeren davranışlar örgütsel vatandaşlık davranışları olarak adlandırılmaktadır. Bireysel düzeyde ele alındığında örgütsel vatandaşlık davranışları kişisel gayrete bağlı eylemlerdir; ancak kolektif olarak örgütsel düzeye taşındığında, örgütün performansına önemli katkılar sağlamaktadır (Podsakoff ve MacKenzie, 1997). Örgütsel vatandaşlık davranışı örgüte, yönetime, gruba ya da bir bireye yardımcı olabilecek olumlu davranışları içermektedir (Brief ve Motowidlo, 1986).

Podsakoff, Mackenzie, Paine ve Bachrach (2000) yaptıkları tarama sonucunda örgütsel vatandaşlık boyutlarının otuz farklı formda incelendiğini gözlemlemişlerdir. Bu çalışmada, kavramın son sınıflaması olarak kabul gören Organ'ın (1988) sınıflandırdığı şekliyle beş boyutlu olarak ele alınmıştır. Yardımlaşma boyutu, işgörenlerin işle ilgili konularda çalışma arkadaşlarına gönüllü olarak yardım etmeyi içerir. Bu davranışlar örgütteki işbirliğini destekleyici niteliktedir. Nezaket davranışları, birbirleriyle etkileşim halinde olan işgörenlerin, yapılan iş ve alınan kararlarla ilgili birbirlerini haberdar etmeleri şeklinde gelişen olumlu davranışlardır (Demiröz, 2014). Vicdanlılık, işgörenlerin düşük düzeyde gösterilmesi istenen davranışların (kaynakları koruma, dakiklik, katılım, devamlılık) ötesine geçerek beklenenden daha fazlasını göstermelerini içeren davranışlardır (Podsakoff ve diğerleri, 2000). Centilmenlik boyutu, örgütteki dayanışmanın kaçınılmaz bir ürünü olan iş yükü ve sıkıntılara hoşgörü gösterilmesi olarak tanımlanmaktadır. Sivil erdem, örgüte bir 
bütün olarak yüksek düzeyde katılımı (yönetime etkin katılım, örgüt yararını gözetme, toplantılara etkin katılım vb.) içermektedir. İşbirliğine dayalı sosyal bir yapı olan eğitim örgütlerinde öğretmenler arasında yardımlaşma duygularının teşvik edilmesi, kolektif gayret ve takım çalışması, öğretmenlerin örgütsel vatandaşlık davranışları göstermelerine yardımcı olmaktadır. Bu nedenle, öğretmenlerin örgütte alınacak kararlarda söz sahibi olmaları, ödül ve sorumlulukların adil olunduğunu düşünmeleri ve bu hususta yöneticilere güvenmeleri, fikirlerini özgürce ifade ederek kararlara katılmaları, onların örgütsel vatandaşlık gösterme eğilimlerini artırabilir (Sezgin, 2005).

Eğitim örgütlerini diğer örgütlerden ayıran en önemli özelliği girdisinin ve çıtısının insan oluşudur. Örgüt üyeleri, işyerlerine gelirken kendilerine özgü birtakım bireysel ihtiyaçlarını, değerlerini, amaçlarını ve inançlarını da taşırlar (Hoy ve Miskel, 2012). Bu bakımdan örgüt yöneticileri; hedeflere ulaşabilmek, etkili olmak, verimliliği sağlamak ve niteliği yükseltmek için öğretmenlerin davranışlarına ilişkin durumları dikkate almalıdırlar. Eğitim örgütlerinde örgütsel adaletin sağlanması; yönetici ve öğretmenler arasındaki sosyal bağların güçlenmesine, iletişimin yaygınlaşmasına, kaynakların etkin paylaşımına, karşılıklı güven duygularının oluşmasına ve en önemlisi de çalışılabilir uygun bir iş ortamının oluşturulmasına büyük katkı sağlamaktadır (Ayık, Yücel ve Savaş, 2014; Baş, 2010; Demirel, 2009; Karaköse, Altınkurt ve Yılmaz, 2009; Lunenburg ve Ornstein, 2004; Özer, Demirtaş, Üstüner ve Cömert, 2006; Yıldırım, 2007;).

Örgütsel adalet, araştırmalara konu olan yeni bir kavram olmamasına rağmen eğitim bilimleri alanında sinırlı sayıda araştırmanın olduğu görülmektedir (Buluç, 2015). Örgütsel adaletin önemli bir sonucu olan örgütsel vatandaşlık davranışı (Ali, Ahmad ve Saeed, 2018; Ghazi ve Jalali, 2017) örgüt üyeleri arasındaki işbirliğini geliştirerek örgütün ortak hedeflerine katkı sağlar (Organ, 1990). Özgün bir örgüt kültürü yaratmak ve örgütün etkililik ve verimliliğini arttırmak isteyen yöneticiler için işgörenlerin örgütsel adalet ve örgütsel vatandaşlık düzeylerini belirlemek, yol gösterici olacaktır. Kişisel ve örgütsel bağlamda önemli etkiye sahip olan örgütsel adalet ve örgütsel vatandaşlık davranışı kavramlarına ilişkin daha genel yargılara ulaşılması amacıyla yapılan bu araştırma ile alanyazına katkı sağlanacağı düşünülmektedir.

Eğitim örgütlerinin en önemli sosyal sermeyesi öğretmendir. Öğretmenlerin sahip olduğu algılar ve gösterdikleri davranışlar örgütün işlevlerini yerine getirmesini doğrudan etkilemektedir. Bu bağlamda bireyin ve örgütün etkililiğine katkı sağlayan örgütsel adalet ve örgütsel vatandaşlık davranışlarının eğitim örgütleri için ne ifade ettiğinin bilinmesi, öğretmen ve yönetici davranışlarının daha iyi analiz edilmesini kolaylaştırabilir. İlkokul, ortaokul ve liselerde görev yapan öğretmenlerin örgütsel adalet algıları ve örgütsel vatandaşlık davranışları arasındaki ilişkiyi incelemeyi amaçlayan bu araştırmada aşağıdaki sorulara cevap aranmıştır:

1. Öğretmenlerin örgütsel adalet algıları ne düzeydedir?

2. Öğretmenlerin okullarında sergiledikleri örgütsel vatandaşlık davranışlarına ilişkin algıları ne düzeydedir?

3. Öğretmenlerin örgütsel adalet algıları ve örgütsel vatandaşlık davranışlarına ilişkin algıları arasında ilişki var mıdır?

4. Öğretmenlerin örgütsel adalet ve alt boyutlarına ilişkin alg1 düzeyi, örgütsel vatandaşlık davranışlarının ne kadarını açıklamaktadır?

\section{Yöntem}

\section{Araştırma Modeli}

Öğretmenlerin örgütsel adalet algıları ile örgütsel vatandaşlık davranışları arasındaki ilişkiyi saptamaya yönelik olan bu araştırma ilişkisel tarama modelindedir.

\section{Örneklem}

Araştırmanın örneklem grubunu 2017-2018 eğitim öğretim yılında İstanbul ili Pendik ilçesinde ilkokul, ortaokul, imam hatip ortaokulu, anadolu lisesi, mesleki ve teknik anadolu lisesi ve anadolu imam hatip lisesi türündeki devlete bağlı 36 farklı okulda görev yapan 721 öğretmen oluşturmuştur. Örneklem grubunu 
belirlemede olasılığa dayalı olmayan kolayda örnekleme yöntemi kullanılmıştır. Kolayda örnekleme yöntemi, ölçeklere cevap veren herkesin örnekleme dâhil edilebilmesi esasına dayanmaktadır (Altunışık, Coşkun, Bayraktaroğlu ve Yıldırım, 2012). Bu yöntemde araştırma için ihtiyaç duyulan örneklem büyüklüğü kolay ve ulaşılabilir katılımcılar ile oluşturulur (Gürbüz ve Şahin, 2016).

Araştırma kapsamında yer alan örneklem grubunu oluşturan öğretmenlerin 450'si (\%62,4) kadın ve 271'i $(\% 37,6)$ erkektir. Okul türlerine bakıldığında ilkokulda $130(\% 18,0)$, ortaokulda $131(\% 18,2)$, imam-hatip ortaokulunda $112(\% 15,5)$, anadolu lisesinde 126 (\%17,5), mesleki ve teknik anadolu lisesinde $106(\% 14,7)$ ve anadolu imam-hatip lisesinde 116 (\%16,1) öğretmen olarak bulunmaktadır. Öğretmenlerin 193' ü (26,8) 1-5 yıl, 204 '̈̈ (\%28,3) 6-10 yıl, 103'ü (\%14,3) 11-15 y1l, 117'si (\%16,2) 16-20 yıl, 104'ü (\%14,4) ise 21 yıl ve daha fazla mesleki kıdeme sahiptir. Öğretmenlerin bağlı bulundukları kurumlardaki çalışma sürelerine bakıldığında 546'sının (\%75,7) 1-5 yıl, 124'ünün (\%17,2) 6-10 yıl, 51'inin ise 11 yıl ve daha fazla kıdeme sahip olduğu görülmektedir.

\section{Araştırmada İzlenen Etik İlkeler}

$\mathrm{Bu}$ araştırmada tüm veriler, bilimsel yöntemlerle elde edilmiştir. Elde edilen verilerin değerlendirilmesinde, yorumunda ve kuramsal sonuçların elde edilmesinde bilimsel yöntemlerin dışına çıkılmamış, sonuçlar saptırılmamıştır. Araştırma verilerini toplayabilmek için öncelikle İstanbul İl Milli Eğitim Müdürlüğünden gerekli izinler alınmıştır. Araştırma verilerinin toplandığı tüm öğretmenlerin rızası alınmış ve katılımclara araştırma hakkında bilgi verilerek araştırmanın bilimsel nitelik taşıdığı, gizlilik esaslarına göre katılımcıların isimlerinin kullanılmayacağı taahhüt edilmiştir. Araştırmada bilimsel atıf kurallarına uygun olarak kaynak gösterilmiş ve çalı̧̧manın sonunda intihal raporu alınmıştır.

\section{Veri Toplama Araçları}

Bu araştırmada kişisel bilgi formu ile birlikte Örgütsel Adalet Ölçeği ve Örgütsel Vatandaşlık Davranışı Ölçeği kullanılmıştır.

Kişisel bilgi formunda öğretmenlerin cinsiyet, çalıştıkları okul türü, mesleki kıdem, sendika üyeliği ve mevcut kurumlarındaki çalışma sürelerine ilişkin bilgiler elde edilmiştir.

Öğretmenlerin örgütsel adalet algılarını ölçmek amacıyla Niehoff ve Moorman (1993) tarafından geliştirilen ve Polat (2007) tarafından Türkçeye uyarlanan “Örgütsel Adalet Ölçeği” kullanılmıştır. Ölçek, toplam 19 madde ve 3 boyuttan oluşmaktadır. Bu boyutlar: Dağıtımsal adalet, işlemsel adalet ve etkileşimsel adalet şeklinde sınıflandırılmıştır. Polat (2007) ölçeğin tamamı için Cronbach's Alpha güvenirlik katsayısını $\alpha=.96$; örgütsel adaletin alt boyutları için ise dağıtımsal adalet $\alpha=.89$, işlemsel adalet $\alpha=.95$ ve etkileşimsel adalet boyutunda $\alpha=.90$ olarak hesaplamıştır. Bu araştırmada aynı ölçek için yapılan güvenirlik analizi sonucu Cronbach's Alpha katsayısı $\alpha=.96$ olarak hesaplanmıştır. Örgütsel adaletin alt boyutlarına ilişkin sonuçlar ise dağıtımsal adalet $\alpha=.88$, işlemsel adalet $\alpha=.95$ ve etkileşimsel adalet $\alpha=.92$ olarak hesaplanmıştır.

Öğretmenlerin örgütsel vatandaşlık davranışları algısı Podsakoff ve MacKenzie (1989) tarafından oluşturulan, Podsakoff, MacKenzie, Moorman ve Fetter (1990) ve Moorman (1991) tarafından geliştirilen ve Polat (2007) tarafından Türkçeye uyarlanan "Örgütsel Vatandaşlık Davranışı Ölçeği” ile ölçülmüştür. Ölçek, Organ'ın (1988) örgütsel vatandaşlık davranışının beş boyutuna dayalı olarak hazırlanmıştır. Polat (2007) tarafından yapılan faktör analizi sonucunda aslı 5 boyutlu olan ölçek, 4 boyutta toplanmıştır. Bu boyutlar; yardımlaşma, centilmenlik, vicdanlılık ve sivil erdem şeklindedir. Yapılan güvenirlik analizinde tüm ölçeğin Cronbach's Alpha katsayısı $\alpha=.89$ olarak hesaplanmıştır. Faktör analizine dayalı boyutlar için yapılan güvenirlik hesabında ise yardımlaşma boyutunda $\alpha=.86$; centilmenlik boyutunda $\alpha=.81$; vicdanlılık boyutunda $\alpha=.88$ ve sivil erdem boyutunda ise $\alpha=.82$ çıkmıştır (Polat, 2007, s. 98-99). Bu araştırmada yapılan tüm ölçek için yapılan güvenirlik analizinde Cronbach's Alpha katsayısı $\alpha=.82$ olarak hesaplanmıştır. Örgütsel vatandaşlık davranışlarının alt boyutlarında ise yardımlaşma boyutunda $\alpha=.80$, centilmenlik boyutunda $\alpha=.79$, vicdanlılık boyutunda $\alpha=.69$, sivil erdem boyutunda $\alpha=.76$ olarak hesaplanmıştır. 


\section{Verilerin Analizi}

Araştırma verilerinin analizine başlamadan önce verilere ilişkin çarpıklık ve basıklık değerlerinin sırasıyla -,30 ile -,19 ve -,46 ile ,11 aralığında yer aldığı saptanarak verilerin normal dağıldığı kabul edilmiştir (Hair, Black, Babin, Anderson ve Tatham, 2013). Veri toplama araçlarındaki her boyut için toplam puanlar, toplam puanlara göre standart sapma (ss) ve aritmetik ortalama hesaplanmış ve tablolaştırılmıştır. Değişkenlerin birbirleriyle ilişkisinin şiddetini ve yönünü saptamak için korelasyon analizi uygulanmıştır. Korelasyon katsayıları "0,70-1,00" aralığında "yüksek", "0,69-0,30" aralığında "orta", 0,29 ve daha az değerde ise "düşük" düzey olarak yorumlanmıştır (Büyüköztürk, 2006). Yordayıcı (bağımsız) değişkenler ile yordanan (bağımlı) değişken arasında doğrusal bir ilişki olup olmadığını ve bağımsız değişkenlerin bağımlı değişkenleri ne kadar açıladığını tespit etmek amacıyla regresyon analizi uygulanmıştır. Verilerin istatistiksel analizi ve yorumlarda $\mathrm{p}<.01$ anlamlılık düzeyi dikkate alınmıştır.

\section{Bulgular}

Bu bölümde katılımcılara ilişkin demografik bilgiler ile araştırmanın amacı ve alt amaçları doğrultusunda elde edilen verilere ilişkin bulgular yer almaktadır.

Araştırmaya katılan öğretmenlerin örgütsel adalet ve alt boyutlarına ilişkin algı düzeylerinin aritmetik ortalama ve standart sapma değerleri aşağıda Tablo 1'de gösterilmiştir.

Tablo I

Örgütsel Adalet ve Alt Boyutlarına İlişkin Aritmetik Ortalama ve Standart Sapma Değerleri

\begin{tabular}{|c|c|c|c|}
\hline Alt Boyutlar & $\mathbf{N}$ & $\bar{X}$ & Ss \\
\hline Dağıtımsal Adalet & \multirow{4}{*}{721} & 3,36 & 88 \\
\hline İşlemsel Adalet & & 3,27 & ,93 \\
\hline Etkileşimsel Adalet & & 3,77 & 91 \\
\hline Örgütsel Adalet Toplam & & 3,41 & 84 \\
\hline
\end{tabular}

Araştırmada elde edilen bulgulara göre öğretmenlerin örgütsel adalet algıları $(\bar{X}=3,41)$ "yüksek" düzeydedir. Örgütsel adaletin alt boyutları incelendiğinde öğretmenlerin dağıtımsal adalet $(\bar{X}=3,36)$ ve işlemsel adalet $(\bar{X}=3,27)$ boyutlarına ilişkin algılarının "orta" düzeyde, etkileşimsel adalet boyutunun $(\bar{X}=3,77)$ ise "yüksek" düzeyde olduğu görülmüştür.

Araştırmaya katılan öğretmenlerin örgütsel vatandaşlık ve alt boyutlarına ilişkin algı düzeylerinin aritmetik ortalama ve standart sapma değerleri aşağıda Tablo 2'de gösterilmiştir.

Tablo II

Örgütsel Vatandaşlık Davranışları ve Alt Boyutlarına İlişkin Ortalama ve Standart Sapma Değerleri

\begin{tabular}{|c|c|c|c|}
\hline Alt Boyutlar & $\mathbf{N}$ & $\overline{\mathrm{X}}$ & Ss \\
\hline Yardımlaşma & \multirow{5}{*}{721} & 3,93 &, 59 \\
\hline Centilmenlik & & 4,28 & ,73 \\
\hline Vicdanlılık & & 4,33 & 67 \\
\hline Sivil Erdem & & 3,70 & ,72 \\
\hline Örgütsel Vatandaşlık Toplam & & 4,03 & 44 \\
\hline
\end{tabular}

Öğretmenlerin örgütsel vatandaşlık davranışları sergileme düzeyinin $(\bar{X}=4,03)$ "yüksek" olduğu bulunmuştur. Örgütsel vatandaşlık davranışlarının alt boyutlarına ilişkin ortalamalara bakıldığında öğretmenlerin vicdanlılık $(\bar{X}=4,33)$ ve centilmenlik $(\bar{X}=4,28)$ davranışlarını "çok yüksek" düzeyde sergiledikleri saptanmıştır. Yardımlaşma $(\bar{X}=3,93)$ ve sivil erdem $(\bar{X}=3,70)$ boyutlarını oluşturan davranışların ise "yüksek" düzeyde sergilendiği saptanmıştır.

Öğretmenlerin örgütsel adalet algıları ile örgütsel vatandaşlık davranışlarına ilişkin korelasyon değerleri Tablo 3'te verilmiştir. 
Tablo III

Örgütsel Adalet Algıları ve Örgütsel Vatandaşlık Davranışları Arasındaki İlişki

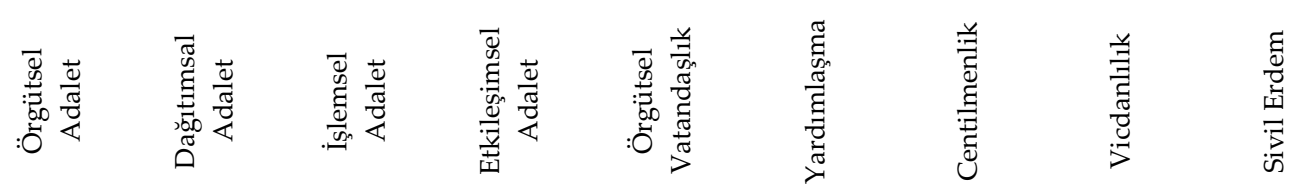

\begin{tabular}{|c|c|c|c|c|c|c|c|c|c|}
\hline Örgütsel Adalet & 1 & $900^{* *}$ & $963^{* *}$ & $878^{* *}$ & $257^{* *}$ &, $189^{* *}$ & $156^{* *}$ &, $101^{* *}$ &, $220^{* *}$ \\
\hline Dağıtımsal Adalet &, $900^{* *}$ & 1 &, $783^{* *}$ & $705^{* *}$ & $217^{* *}$ &, $177^{* *}$ &, $145^{* *}$ & 053 &, $176^{* *}$ \\
\hline İşlemsel Adalet &, $963^{* *}$ &, $783^{* *}$ & 1 & $800^{* *}$ & $250 * *$ &, $180^{* *}$ & $123^{* *}$ & $109^{* *}$ & ,240* \\
\hline Etkileşimsel Adalet &, $878^{* *}$ &, $705^{* *}$ & $800^{* *}$ & 1 & $239^{* *}$ &, $161^{* *}$ & $192^{* *}$ &, $120^{* *}$ &, $159^{* *}$ \\
\hline Örgütsel Vatandaşlık &, $257^{* *}$ & $217^{* *}$ & $250^{* *}$ & $239^{* *}$ & 1 & $820^{* *}$ & $480^{* *}$ &, $555^{* *}$ &, $705^{* *}$ \\
\hline Yardımlaşma &, $189^{* *}$ &, $177^{* *}$ &, $180^{* *}$ &, $161^{* *}$ &, $820^{* *}$ & 1 &, $131^{* *}$ & $250^{* *}$ &, $501^{* *}$ \\
\hline Centilmenlik &, $156^{* *}$ &, $145^{* *}$ &, $123^{* *}$ & $192^{* *}$ & $480^{* *}$ &, $131^{* *}$ & 1 &, $123^{* *}$ &, $119^{* *}$ \\
\hline Vicdanlılık &, $101^{* *}$ & ,053 & $109^{* *}$ &, $120^{* *}$ &, $555^{* *}$ &, $250^{* *}$ & $123^{* *}$ & 1 &, $228^{* *}$ \\
\hline Sivil Erdem &, $220^{* *}$ & $176^{* *}$ & $240^{* *}$ & $159^{* *}$ &, $705^{* *}$ &, $501^{* *}$ &, $119^{* *}$ & $228^{* *}$ & 1 \\
\hline
\end{tabular}

${ }^{*}$ Korelasyon 0.05 düzeyinde anlaml 1

** Korelasyon 0.01 düzeyinde anlamlı

Öğretmenlerin örgütsel adalet algıları ile örgütsel vatandaşlık davranışlarına ilişkin algı düzeyleri arasında olumlu ve zayıf düzeyde $(\mathrm{r}=, 257, \mathrm{p}<, 01)$ bir ilişki olduğu görülmüştür. Örgütsel adalet ile örgütsel vatandaşlık davranışlarının yardımlaşma $(\mathrm{r}=, 189, \mathrm{p}<, 01)$, centilmenlik $(\mathrm{r}=, 156, \mathrm{p}<, 01)$, vicdanlılık $(\mathrm{r}=, 101, \mathrm{p}<, 01)$ ve sivil erdem $(\mathrm{r}=, 220, \mathrm{p}<, 01)$ alt boyutları arasında olumlu ve zayıf düzeyde ilişki olduğu saptanmıştır. Örgütsel vatandaşlık davranışları ile örgütsel adaletin dağıtımsal adalet $(r=, 217, p<, 01)$, işlemsel adalet $(r=, 250$, $\mathrm{p}<, 01)$ ve etkileşimsel adalet $(\mathrm{r}=, 239, \mathrm{p}<, 01)$ alt boyutları arasında olumlu ve zayıf düzeyde bir ilişki olduğu tespit edilmiştir. Örgütsel adaletin dağıtımsal adalet alt boyutu ile örgütsel vatandaşlık davranışının yardımlaşma $(\mathrm{r}=, 177, \mathrm{p}<, 01)$ centilmenlik $(\mathrm{r}=, 145, \mathrm{p}<, 01)$ ve sivil erdem $(\mathrm{r}=, 176, \mathrm{p}<, 01)$ alt boyutları arasında olumlu ve zayıf düzeyde ilişki saptanmıştır. Dağıtımsal adalet ile vicdanlılık arasında anlamlı bir ilişki olmadığı görülmüştür $(p>, 05)$. Örgütsel adaletin işlemsel ve etkileşimsel adalet alt boyutları ile örgütsel vatandaşlık davranışlarının tüm alt boyutları arasında olumlu ve zayıf düzeyde ilişki olduğu saptanmıştır.

Örgütsel adaletin örgütsel vatandaşlık davranışlarını açıklamasına ilişkin basit regresyon analizi sonuçları Tablo 4 'te verilmiştir.

Tablo IV

Örgütsel Adaletin Örgütsel Vatandaşlık Davranışların Açılamasına İlişkin Basit Regresyon Analizi Sonuçları

\begin{tabular}{lcccccc}
\hline Model 3 & \multicolumn{3}{c}{ Bağımlı Değişken: Örgütsel Vatandaşlık Davranışları } & & \\
\hline Bağımsız Değişken & $\mathrm{B}$ & $\begin{array}{c}\text { Standart Hata } \\
\mathrm{B}\end{array}$ & $\mathrm{B}$ & $\mathrm{T}$ & $\mathrm{P}$ & $\mathrm{R}$ \\
\hline Sabit & 3,584 &, 066 & - & 54,493 &, 000 & - \\
\hline Örgütsel Adalet &, 133 &, 019 &, 257 & 7,130 &, 000 &, 257 \\
\hline $\mathrm{R}=, 257$ & $\mathrm{R}^{2}=, 066$ & & & & & \\
\hline $\mathrm{F}(1,719)=50,844$ & $\mathrm{P}=, 000$ & & & & \\
\hline
\end{tabular}

Örgütsel adaletin örgütsel vatandaşlık davranışlarına anlamlı düzeyde etki ettiği tespit edilmiştir $(R=, 257$, $\left.\mathrm{R}^{2}=, 066, \mathrm{p}<, 01\right)$. Örgütsel adalet, örgütsel vatandaşlık davranışlarının yaklaşık \%7' sini açılklamaktadır.

Örgütsel adaletin alt boyutlarının örgütsel vatandaşlık davranışını açıklamasına ilişkin çoklu regresyon analizi sonuçları Tablo 5 'te verilmiştir.

Tablo V

Örgütsel Adaletin Alt Boyutlarının Örgütsel Vatandaşlık Davranışlarını Açıklamasına İlişkin Çoklu Regresyon Analizi Sonuçları

\begin{tabular}{|c|c|c|c|c|c|c|c|}
\hline \multirow{2}{*}{$\begin{array}{l}\text { Model } 4 \\
\text { Bağımsız Değişken }\end{array}$} & \multicolumn{7}{|c|}{ Bağımlı Değişken: Örgütsel Vatandaşlık Davranışları } \\
\hline & B & $\begin{array}{c}\text { Standart Hata } \\
\text { B }\end{array}$ & $\beta$ & $\mathrm{T}$ & $\mathrm{P}$ & İkili $r$ & Kismi R \\
\hline Sabit & 3,578 & , 070 & - & 50,835 & 000 & - & - \\
\hline Dağıtımsal & ,018 & 029 & 036 & ,598 & ,550 & 217 & , 022 \\
\hline İşlemsel & 066 & 033 & 140 & 2,001 & 046 & 250 & 075 \\
\hline Etkileşimsel & ,049 & 030 & 102 & 1,661 & 097 & 239 & ,062 \\
\hline
\end{tabular}


Öğretmenlerin Örgütsel Adalet Algıları ile ...

\begin{tabular}{ll}
\hline $\mathrm{R}=, 259$ & $\mathrm{R}^{2}=, 063$ \\
\hline $\mathrm{F}(3,717)=17,229$ & $\mathrm{p}=, 000$ \\
\hline
\end{tabular}

Örgütsel adaletin üç alt boyutu birlikte örgütsel vatandaşlık davranışlarını anlamlı düzeyde açıklamaktadır $\left(R=, 259, R^{2}=, 063, p<, 01\right)$. Adı geçen üç alt boyut birlikte örgütsel vatandaşlık davranışlarındaki toplam varyansın yaklaşık \%6' sını açıklamaktadır. Standardize edilmiş regresyon katsayılarına göre yordayıcı değişkenlerin örgütsel vatandaşlık üzerindeki etkisi önem sırasıyla işlemsel adalet $(\beta=, 140)$, etkileşimsel adalet $(\beta=, 102)$ ve dağıtımsal adalet $(\beta=, 036)$ şeklindedir. Regresyon katsayılarının anlamlılığına ilişkin t-testi sonuçları incelendiğinde işlemsel adalet değişkeninin örgütsel vatandaşlık davranışları üzerinde anlamlı bir yordayıcı olduğu bulunmuştur. Dağıtımsal ve etkileşimsel adalet değişkenlerinin önemli bir etkiye sahip olmadığı saptanmıştır.

\section{Sonuç ve Tartışma}

Araştırma bulgularında öğretmenlerin örgütsel adalet algılarının "yüksek" düzeyde olduğu görülmüştür. Buna göre öğretmenler, çalıştıkları okullarda bulunan yönetimi adil bulmaktadırlar. Bu bulgu birçok araştırma sonucuyla tutarlıdır (Akgüney 2014; Alanoğlu ve Demirtaş, 2019; Batur, 2015; Çırak, 2013; Ertürk, 2011; Kahraman 2014; Öztuğ ve Baştaş, 2012; Polat, 2007; Potuk, 2017; Şahin ve Kavas, 2016). Yapılan bazı araştırmalarda ise (Aydın, 2015; Çavuş, 2016; Günce, 2013; Kuşci, 2014; Uysal, 2014, Yıldız, 2015) örgütsel adalet algılarının "orta" düzeyde olduğu tespit edilmiştir. Adalet kavramının devingen yapısından dolayı birey ve örgüte göre değişen anlamı bu sonucu doğurmuş olabilir. Çünkü bir davranışın adil olması, bireyin o davranışı adil bulmasıyla ilgilidir (Colquitt, Greenberg ve Zapata-Phelan, 2005). Yani adaletin tanımlanması özneldir; örgüt yapısı ve kültürü ile amaçlar bireylerin neyi adil algıladıklarını belirleyen etkenlerdir (Folger ve Cropanzano, 1998).

Örgütsel adaletin alt boyutlarına ilişkin bulgulara göre etkileşimsel adalet alt boyutunun "yüksek"; dağıtımsal ve işlemsel adalet alt boyutlarının ise "orta" düzeyde olduğu görülmüştür. Bu bakımdan öğretmenler, okullarındaki yöneticilerin kişilerarası davranışlarını (nezaket, saygı, duyarlılık vs.) karar alma sürecine ve sonucunda oluşan kazanımların dağıtımına göre daha adil bulmaktadırlar. Başka bir ifadeyle öğretmenler, yöneticilerin kişisel ihtiyaçlarına karşı duyarlı olduklarını, verilen kararları gizlemeden herkese tarafsız bir şekilde açıladıklarını, iletişimlerinde adil olduklarını düşünmektedirler. Buna karşılık karar alma sürecinin ve sonuçta dağıtılan kazanımların yeterince adil olmadığını düşünmektedirler. Okul yöneticilerinin bulundukları konuma uygun mesleki yeterliklerinin olmaması bu sonucu doğurmuş olabilir. Kararların çok seslilikle alınmaması ve ödüllerin adil bir şekilde dağıtılmaması öğretmenlerin motivasyonunu ve performansını olumsuz etkileyen faktörlerdir. Bu farkındalıkla hareket etmeyen yöneticilerin adaletsiz uygulamaları öğretmenleri rahatsız edici sonuçlar doğurmuş olabilir. Kişilerarası ilişkiler daha adil olsa da okulun iş ve işlemlerinin yürütülmesinde uygulanan prosedürler için fikirlerinin alınmadığını ve ödüllerin adil bir şekilde dağıtılmadığını düşünen öğretmenlerin yöneticileri adil bulmadıkları söylenebilir. Bu araştırmanın bulgusundan farklı olarak bazı araştırma sonuçları (Çırak, 2013; Ertürk, 2011; Gök, 2014; Kahraman, 2014, Kılıç, 2013; Polat, 2007; Potuk, 2017) örgütsel adaletin tüm alt boyutlarına ilişkin adalet algilarının "yüksek" düzeyde olduğunu ortaya koymuştur. Gerek bu çalışmada gerek Türkiye'de yapılan birçok araştırmada etkileşimsel adalet alt boyutunun diğer alt boyutlara göre daha yüksek düzeyde olduğu görülmüştür (Alanoğlu ve Demirtaş, 2019; Bolak, Mustafa ve Işık, 2017; Çırak, 2013; Dündar, 2011; Günce, 2013; Polat, 2007; Uludağ, Aktaş ve Özdoğaç Özgit, 2019; Yıldız, 2015).

Bulgularda öğretmenlerin örgütsel vatandaşlık davranışlarını "yüksek" düzeyde sergiledikleri görülmüştür. Başka bir ifadeyle öğretmenler, resmi olarak tanımlanmış rol davranışlarının ötesine geçen gönüllü davranışları sık sık sergilemektedirler. Türkiye' de yapılan birçok araştırma bulgusu bu araştırmada elde edilen bulguyla tutarlıdır (Akgüney, 2014; Bozkurt, 2018; Çelik, 2010; Kubilay Baykal, 2013; Özdemir, 2010; Özdemir Demirel, 2012; Polat, 2007; Tabancalı ve Çakıroğlu, 2017; Yancı, 2011; Yenel, 2016; Yıldırım, 2015). Bazı araştırmacılar (Çetin, 2011; Gökmen, 2011; Kurtulmuş, 2016; Uslu, 2011; Yılmaz, 2012) öğretmenlerin örgütsel vatandaşlık davranışlarının orta düzeyde olduğunu, bazıları ise (Alğan, 2011; Buluç, 2008; Karakuş, 2008; Köprülü, 2011) çok yüksek düzeyde olduğunu tespit etmiştir. 
Örgütsel vatandaşlık davranışlarının alt boyutlarına ilişkin bulgular incelendiğinde öğretmenlerin centilmenlik ve vicdanlılık davranışlarını "çok yüksek", yardımlaşma ve sivil erdem davranışlarını "yüksek" düzeyde sergiledikleri görülmüştür. Alğan (2011) ve Karakuş'un (2008) araştırma sonuçları, bu araştırmada elde edilen sonuçla paralellik göstermektedir. Buna göre öğretmenlerin her zaman mesleğine ve okula ilişkin olumlu bir bakış açısına sahip oldukları, iş yükünden şikâyetçi olmadan sorumluluklarını tam ve zamanında yerine getirdikleri söylenebilir. Mesai arkadaşlarının haklarını gözeterek onlara yardımcı olma davranışlarını ve okulun gelişimine fayda sağlayacak etkinliklere gönüllü bir şekilde katılma davranışlarını ise sık sık sergilemektedirler. Örgütsel vatandaşlık davranışlarının alt boyutlarına ilişkin puanlar incelendiğinde en yüksek değerin vicdanlılık boyutunda olduğu görülmüştür. Bu sonuç, yapılan birçok araştırmada elde edilen sonuçla tutarlılık göstermektedir (Aktaş, 2008; Çelik, 2010; Çetin, 2011; Dağlı, 2015; Göksal, 2017; Günbayı, Dağlı ve Kalkan, 2013; Karakaşoğlu, 2011; Polat, 2007; Polat ve Celep, 2008; Sırıklıgil, 2015; Şayir, 2015; Uğurlu ve Demir, 2016; Yanc1, 2011). En düşük değerin ise sivil erdem boyutunda olduğu saptanmıştır. Elde edilen bu sonuçla örtüşen araştırma bulgusu oldukça fazladır (Aktaş, 2008; Averbek, 2016; Çağlayan, 2014; Çelik, 2010; Dündar, 2012; Göksal, 2017; Günbayı ve diğerleri, 2013; Kubilay Baykal, 2013; Polat ve Celep, 2008; Şayir, 2015; Yıldırım, 2017). Vicdanlılık boyutuna ilişkin bulgular, öğretmenlerin denetim yapılmasa bile işlerini zamanında ve eksiksiz bir şekilde yapmaya her zaman özen gösterdiklerini ortaya koymaktadır. Nitelikli birey yetiştirme sorumluluğu, öğretmenlerin işlerine karşı çok hassas olmalarının nedeni olabilir. Sivil erdem boyutuna ilişkin sonuçlar, öğretmenlerin okulun değişimi ve gelişimi için gayret sarf ederek, okulu ilgilendiren toplantılarda sık sık gönüllü olarak yer aldıklarını göstermektedir. Sivil erdem boyutunu kapsayan davranışların daha az sergilenmiş olması, yapılan toplantı ve etkinliklerin öğretmenler tarafından yeterince faydalı olmadığına inanılması şeklinde yorumlanabilir. Bu araştırmada elde edilen bulgulardan farklı olarak Öztürk Yaman (2015) ve Yaprak Kaya (2015), vicdanlılık boyutunun en düşük, sivil erdem boyutunun ise en yüksek değere sahip olduğunu bulmuşlardır. Alanoğlu (2014) ve Tabancalı ve Çakıroğlu'nun (2017) araştırmaları ise en düşük düzeyin yardımlaşma boyutunda olduğunu göstermiştir.

Araştırmada öğretmenlerin örgütsel adalet algıları ile örgütsel vatandaşlık davranışları arasında olumlu ve zayıf düzeyde bir ilişki olduğu tespit edilmiştir. Bu sonuç, birçok araştırma sonucuyla örtüşmektedir (Akgüney, 2014; Ali ve diğerleri, 2018; Dong ve Phuong, 2018; Karriker ve Williams, 2009; Laçinoğlu, 2010; Mohammad, Quoquab ve Adnan, 2010; Moorman, 1991; Organ ve Moorman, 1993; Polat, 2007; Tan, 2017). Yapılan bazı araştırmalarda (Alanoğlu ve Demirtaş, 2019; Polat ve Celep, 2008) öğretmenlerin örgütsel adalet algıları ile örgütsel vatandaşlık davranışları arasında olumlu ve orta düzeyde ilişki olduğu sonucuna ulaşılmıştır. Örgüt yönetimini adil bulan öğretmenler, örgütsel vatandaşlık davranışları sergileme eğilimindedirler. Örgüt yöneticilerinin tavır ve tutumlarının adil olması, öğretmenlerin kendilerini örgütün değerli bir üyesi olarak görmelerini sağlamaktadır. Tarafsız, farklılıklara karşı saygıllı, karar verme sürecinde etkin katılımı sağlayan adil bir yönetim anlayışı, örgüte büyük fayda sağlayacak gönüllü davranışların sergilenme sıklığını artıracaktır. Bunun sebebi etiğe ve ahlaka uygun olarak yürütülen iş ve işlemlerin öğretmenlerde aidiyet duygusu oluşturması olabilir. Örgütteki her bir üyenin sağladığı katkı ile elde ettiği kazanımların oranı adil olduğunda daha fazla katkı sağlama isteği oluşacaktır. Etkin koordinasyon ve sosyal dinamizm için örgüt üyelerinin kendilerini örgütün önemli bir paydaşı olarak tanımlamaları gerekmektedir. Kararların, tavırların, ödüllerin kişiye ve zaman göre değişmediğini düşünen öğretmenler, gerçekleşmesi zorunlu olmayan davranışları gönüllü olarak sergilemektedirler. Bu olumlu katkılar bireysel olarak öğretmenlerin performansını örgütsel olarak okulun işlevselliğini artırıcı niteliktedir.

Örgütsel adaletin dağıtımsal adalet alt boyutu ile örgütsel vatandaşlık davranışlarının geneli ve yardımlaşma, centilmenlik, sivil erdem alt boyutlarını kapsayan davranışlar arasında olumlu ve zayıf düzeyde ilişki saptanmıştır. Buna göre öğretmenler emeklerinin karşılığı olan kazanımların dağıtımını adil olarak algıladıklarında örgütün yararına kendilerinden beklenen sorumluluklardan daha fazlası için çaba harcamaktadırlar. Buna karşılık dağıtımın adil olmadığı algısı oluştuğunda gösterilen çabalar çoğu zaman azaltılır (Harder, 1992). Performans girdi-çıktı oranında lehlerine bir adaletsizlik algılandığında ise suçluluk duygusu yaşayabilirler (Folger ve Cropanzano, 1998; Gilliland, 1994; Greenberg, 1988). Bundan dolay1 kazanımların dağıtımında yaşanan adaletsizlik öğretmenlerin ve eğitim örgütlerinin gelişimlerinin önünde önemli bir engeldir. Ödüllerin ve sorumlulukların hakkaniyetli bir şekilde dağıtılması ile yardımlaşma, yapıcı 
ilişkiler kurma, örgütsel kaynakları koruma, kimse denetlemese bile işi zamanında yapma, olumsuzluklara karşı hoşgörülü olma, örgütsel stratejilere katkı sunma gibi örgütün işlevselliğini artıracak davranışların daha sık sergilenmesi sağlanacaktır. Colquitt'e (2012) göre algılanan dağıtımsal adalet düzeyi yükseldikçe bireyler örgütsel eylemlerde daha istekli olmaktadırlar.

Örgütsel adaletin işlemsel ve etkileşimsel adalet alt boyutları ile örgütsel vatandaşlık davranışlarının geneli ve tüm alt boyutları arasında olumlu ve zayıf düzeyde bir ilişki olduğu görülmüştür. İşlemsel adalet alt boyutu kapsamında karar verme, planlama gibi yönetsel eylemlerin öğretmenler tarafından adil algılanması, mevzuatta belirlenmiş ve zorunlu olan davranışlardan daha fazlası için çaba harcamalarını sağlayacaktır. Bu bakımdan yöneticilerin karar verme sürecini yüksek katılım ve şeffaflıkla yürütmeleri gerekmektedir. Her bireyin düşüncesini ve değerini içermesi gereken, bağımsız ve tarafsız olarak alınan kararlar öğretmenler tarafından daha kolay benimsenecektir. İşlemsel adaletin önemli bir unsuru olan söz hakkı prensibi açısından bakıldığında işlemsel adaletin olmadığı ortamlarda takım çalışması yapmanın güç olduğu söylenebilir (Konovsky, 2000). Öğretmenler karar verme süreçlerinin adil olmadığına inandıklarında, işverenlerine bağlılıkları, performansları ve yardımseverlikleri daha az olmakta; iş değiştirme istekleri daha fazla olmaktadır (Polat, 2007). Greenberg (1990), adil yöntemlerin ve uygulamaların örgütsel performansı geliştirdiğini ifade etmiştir.

Etkileşimsel adalet boyutunu oluşturan kişilerarası ilişkilerin, tavır ve tutumların öğretmenler tarafından adil algılanması yapılması zorunlu olmayan davranışları sergileme sıklığını artırmaktadır. Bazı araştırmacılar örgütsel performansın istenen düzeyde olması bakımından etkileşimsel adaleti işlemsel adaletten daha önemli bulmaktadırlar (Bies, 1987; Moorman, 1991). Çünkü etkileşimsel adalet yönetime ve örgüte karşı geliştirilen tutuma doğrudan etki etmektedir. Araştırma sonucuna göre iletişim, nezaket, saygı ve duyarlılık gibi sosyal ilişkilerin niteliğini belirleyen unsurların adil olmaması örgütün verimliliği ve üretkenliği için bir tehdittir. Buna karşılık sosyal etkileşimin adil olması öğretmenlerin örgüte karşı olumlu tutum ve davranışlar sergilemelerini sağlamaktadır. Bies ve Shapiro' nun (1987) araştırmalarına göre uygulama esnasında iletişimin adil olmadığını düşünen işgörenler daha düşük performans göstermeye ve çalışmaya yönelik olumsuz tutumlara eğilimlidir. Bu bakımdan okul yöneticileri öğretmenlere karşı önyargılarda uzak bir şekilde saygılı ve nazik olmalıdırlar.

Araştırma sonucunda örgütsel adaletin örgütsel vatandaşlık davranışlarını anlamlı düzeyde yordadığı görülmüştür. Bu sonuç, birçok araştırma sonuyla örtüşmektedir (Akgüney, 2014; Dong ve Phuong, 2018; Karriker ve Williams, 2009; Laçinoğlu, 2010; Mohammad ve diğerleri, 2010; Moorman, 1991; Organ ve Moorman, 1993; Tan, 2017). Bu sonuca göre örgütlerini adil bulan öğretmenler, kendilerine değer verildiğini hissederek örgütlerine olumlu yönde etki edecek girdiler oluşturma gayretindedirler. Ali ve diğerleri (2018), örgütsel adaletin işgörenlerin güvenini artırarak örgütsel vatandaşlık davranışları göstermelerini sağladığını ifade etmişlerdir. Örgütsel hedeflere ulaşmak için yöneticilerin dürüst, tutarlı, bağımsız ve ön yargısız eylemler gerçekleştirmeleri gerekmektedir. Adil bir şekilde verilen sorumluluk ve ödüller, hep birlikte alınan kararlar ile kolektif çalışmaların dolayısıyla örgütsel performansın artacağı söylenebilir.

Analiz sonuçlarına göre örgütsel adaletin dağıtımsal, işlemsel ve etkileşimsel adalet boyutları birlikte örgütsel vatandaşlık davranışlarını anlamlı düzeyde yordamaktadırlar. $\mathrm{T}$ değerlerinin anlamlılı̆ına bakıldığında sadece işlemsel adaletin örgütsel vatandaşlık davranışlarını anlamlı düzeyde yordadığı görülmüştür. Bu sonuç birçok araştırma sonucuyla (Akgüney, 2014; Laçinoğlu, 2010; Mohammad ve diğerleri, 2010; Polat, 2007) örtüşmektedir. Dağıtımsal ve etkileşimsel adalet boyutları ise örgütsel vatandaşlığının yordayıcıları değildir. Yapılan bazı araştırmalarda dağıtımsal adaletin (Akgüney, 2014; Laçinoğlu, 2010; Sökmen, Şahal ve Söylemez, 2015), bazılarında ise etkileşimsel adaletin (Laçinoğlu, 2010; Mohammad ve diğerleri, 2010; Polat, 2007; Yangın, 2015) örgütsel vatandaşlık davranışlarını yordadığı tespit edilerek bu araştırmanın sonuçlarıyla uyuşmayan sonuçlara ulaşılmıştır. Ghazi ve Jalali (2017) yaptıkları araştırmada dağıtımsal ve işlemsel adalet boyutlarının örgütsel vatandaşlık davranışını anlamlı düzeyde yordadığını tespit etmişlerdir. Analiz sonuçlarında karar verme ve kararları uygulama sürecine ilişkin adalet algısının sergilenen örgütsel vatandaşlık davranışlarına etki ettiği görülmüştür. Bu bakımdan yöneticiler, uygulama esnasından öğretmenlerin fikirlerini değerli bulmalı, tarafsız ve bağımsız olmalı, kararları kişiye göre 
değiştirmemeli, rasyonel temellere dayandırmalıdır. Örgüte ilişkin kararlarda söz sahibi olan öğretmenler, iş ve işlemleri adil algıladıklarında örgütsel amaçlara ulaşmak ve örgütü korumak amacıyla işbirliği içerisinde gönüllü davranışlar sergileyeceklerdir. Adil yöntemler ve uygulamalar örgüt performansının kabulünü kolaylaştırması bakımından büyük bir öneme sahiptir.

Özellikle merkeziyetçi yönetim anlayışına dayanan eğitim örgütlerinde yalnızca belirli görevlerin yerine getirilmesiyle hedeflere ulaşmak mümkün değildir. Örgütlerin işlevselliğini korumak ve varlıklarını sürdürmek için iş tanımında yer almayan, fazladan gayret ve özveri gerektiren kolektif eylemlere ihtiyaç vardır. Emredilemeyen ve önceden tanımlanamayan bu davranışların gerçekleşmesi için adil eğitim ortamlarına ve öğretmenleri motive edici liderlere ihtiyaç vardır. Yöneticisini bağımsız bulan, kazanımlarının güvence altında olduğunu bilen, örgütsel faaliyetlerde söz hakkına sahip olan öğretmenler işbirliği içinde örgüte fayda sağlamaya daha istekli olacaklardır. Çünkü adil yönetim, öğretmenlerin kendilerini örgütün değerli bir vatandaşı olarak görmelerini sağlamaktadır. Bu bağlamda sergilenen davranışlar yönetmelikle açıkça belirtilen, zorunlu rol davranışları değil kişisel seçimlerdir. Bireysel performansı ve örgütsel verimliliği artıran örgütsel vatandaşlık davranışlarının daha sık sergilenmesi için yöneticilerin adil okul iklimlerini oluşturmaları gerekmektedir. Aidiyet duygusuyla ortaya çıkan takım çalışmalarıyla topluma daha nitelikli çıtılar sunulabilir.

Araştırma 2017-2018 eğitim öğretim yılında İstanbul ili Pendik ilçesindeki devlet ilkokul, ortaokul, imam hatip ortaokulu, anadolu lisesi, mesleki ve teknik anadolu lisesi, anadolu imam hatip lisesi türünde okullarda görev yapan öğretmenlerle sınırlıdır. İlçe genelinde görev yapan öğretmenlerin mesleki deneyimlerinin 1-5 yıl arasında olması da başka bir sınırlılık olarak kabul edilebilir. Kolayda örnekleme yöntemi ile elde edilen verilere ilişkin bulgular genellenemez. Araştırma bulgularına dayalı olarak uygulayıcılar ve araştırmacılara birtakım öneriler geliştirilmiştir. Öğretmenlerin örgütsel adalet algılarını daha yüksek düzeye çıkarmak için yöneticiler; ödül, ders programı ve sorumlulukları etik değerlere bağlı kalarak hakkaniyetli bir şekilde dağıtmalıdırlar. Bununla birlikte istenmesi durumunda okula ilişkin kararların gerekçelerini şeffaf bir şekilde açıklamalıdırlar. Öğretmenlerin okul yararına sergiledikleri gönüllü davranışları her zaman düzeyine çıkarmak için aidiyet duygusunu artıracak sosyal etkinlikler düzenlenebilir. Ayrıca okulun etkili ve verimli bir şekilde varlığını sürdürebilmesi için hazırlanan stratejik plan ve hedeflerin tüm öğretmenlerce belirlenmesi kolektif eylemlerin oluşmasını sağlayabilir. Öğretmenlerin örgütsel adalet algıları ile örgütsel vatandaşlık davranışlarının ilişkili olduğu saptanmıştır. Okulu doğrudan etkileyen bu kavramların önemi bilimsel çalışmalar ve seminerler yoluyla yöneticilere aktarılabilir. Bu araştırma İstanbul ili Pendik ilçesi özelinde yapılmıştır. Benzer araştırmalar farklı bölgelerde yapılarak daha genel yargılara varılabilir. Bu araştırma niceldir. Nitel araştırma yöntemleri ile benzer araştırmalara yapılarak kavramlar farklı açlardan irdelenebilir. Özel okullarda görev yapan öğretmenlerin tutumlarını ölçmeye yönelik benzer araştırmalar yapılabilir.

\section{Yazar(lar)ın Beyanı}

Araştırmacıların katkı oranı beyanı: Araştırmacılardan Aykut Günȩ̧ Yüksek Lisans öğrencisi, Rüyam Küçüksüleymanoğlu Yüksek Lisans tez danışmanı olarak katkı sunmuştur. Araştırmanın verileri doğrudan birinci yazar tarafından toplanmıştır. Her iki yazar, araştırmanın giriş, yöntem, bulgular, tartışma ve sonuç bölümlerine katkıda bulunmuştur.

Çatışma beyanı: Araştırmada, yazarların kendi içinde ve diğer kişi/kurum/kuruşlarla herhangi bir çıkar çatışması söz konusu değildir.

Destek ve teşekkür: Araştırmanın yürütülmesinde herhangi bir kurumdan destek alınmamıştır.

\section{Kaynaklar}

Adams, J. S. (1965). Inequity in social exchange. Advances in Experimental Social Psychology, 2, 267-299.

Akgüney, E. (2014). Öğretmenlerin örgütsel adalet algılamaları ile örgütsel vatandaşlık davranışları arasındaki ilişki (Yayımlanmamış yüksek lisans tezi). Marmara Üniversitesi, İstanbul. 
Aktaş, H. G. (2008). Öğretmenlerde denetim odağı ve örgütsel vatandaşlık (Yayımlanmamış yüksek lisans tezi). Afyon Kocatepe Üniversitesi, Afyon.

Alanoğlu, M. (2014). Ortä̈ğretim kurumlarının örgütsel öğrenme düzeylerinin okul etkililiği ve örgütsel vatandaşlı davranışlarına etkisi (Yayımlanmamış yüksek lisans tezi). Fırat Üniversitesi, Elazı̆̆.

Alanoğlu, M. ve Demirtaş, Z. (2019). Öğretmenlerin örgütsel adalet algılarının örgütsel vatandaşlık davranışı üzerindeki etkisi. Marmara Üniversitesi Atatürk Ĕ̆itim Fakültesi Ĕ̆itim Bilimleri Dergisi, 49(49), 1-16.

Alğan, Y. (2011). Örgütsel vatandaşlık davranışlart ile problem çözme becerilerine yönelik yönetici ve öğretmen görüşleri "Bolu ili merkez ilçe örneği" (Yayımlanmamış yüksek lisans tezi). Abant İzzet Baysal Üniversitesi, Bolu.

Ali, A., Ahmad, S. ve Saeed, I. (2018). Ethical leadership and organizational citizenship behaviour: Mediating role of organizational justice: A case study of education sector. Abasyn Journal of Social Sciences, 11(2), 386399.

Altunışık, R., Coşkun, R., Bayraktaroğlu, S. ve Yıldırım, E. (2012). Sosyal bilimlerde araştırma yöntemleri (SPSS uygulamalı). Sakarya: Sakarya Yayıncilı.

Atalay, İ. (2005). Örgütsel vatandaşlık ve örgütsel adalet (Yayımlanmamış yüksek lisans tezi). Afyon Kocatepe Üniversitesi, Sosyal Bilimler Enstitüsü, Afyon.

Averbek, A. (2016). İlkokullarda görevli öğretmenlerin örgütsel yabancılaşma ile örgütsel vatandaşlı davranışları arasındaki ilişki (Yayımlanmamış yüksek lisans tezi). Dicle Üniversitesi, Diyarbakır.

Aydın, K. (2015). Illkokul ve ortaokul öğretmenlerinin örgütsel adalet algılarn ile işe yabancılaşma algıları arasındaki ilişki (Uşak ili örneği) (Yayımlanmamış yüksek lisans tezi). Uşak Üniversitesi, Uşak.

Ayık A., Yücel E. ve Savaş M. (2014). Öğretmenlerin örgütsel adalet algılarının yordayıcısı olarak okul yöneticilerinin etik liderlik davranışları. Abant İzzet Baysal Üniversitesi Eğitim Fakültesi Dergisi, 14(2), 233252.

Bal, V. (2014). Örgütsel adalet ve örgütsel bağlllık ilişkisi: Manisa' daki eğitim kurumlarında bir araştırma. Aksaray Üniversitesi İktisadi İdari Bilimler Fakültesi Dergisi, 6(1), 1-9.

Baş, G. (2010). İlköğretim okulu öğretmenlerinin örgütsel adalet ve örgütsel güven düzeyleri arasındaki ilişki. Eğitim ve Insani Bilimler Dergisi: Teori ve Uygulama, 1(2), 17-36.

Batur, M. (2015). Öğretmen algılarına göre etik liderlik ile örgütsel adalet arasındaki ilişki (Yayımlanmamış yüksek lisans tezi). Zirve Üniversitesi, Gaziantep.

Berber, A. (2010). Çalışanların örgütsel adalet algılamalar ile örgütsel vatandaşlık davranışları arasındaki ilişkinin incelenmesine yönelik bir uygulama (Yayımlanmamış yüksek lisans tezi). Yıldız Teknik Üniversitesi, İstanbul.

Beugré, C. D. (2002). Understanding organizational justice and its impact on managing employees: An African perspective. International Journal of Human Resource Management, 13(7), 1091-1104.

Bies, R. J. (1987). The predicament of injustice: The management of moral outrage. Research in Organizational Behavior, 9, 289-319.

Bies, R. J. ve Shapiro, D. L. (1987). Interactional fairness judgments: The influence of causal accounts. Social Justice Research, 1(2), 199-218.

Bolak, H., Mustafa, Ö. ve Işık, M. (2017). Milli Eğitim Bakanlığına bağlı ortaöğretim kurumlarında örgütsel adalet ve çatışma yönetimi ilişkisi (Denizli örneği). Mehmet Akif Ersoy Üniversitesi Sosyal Bilimler Enstitüsü Dergisi, 9(20), 69-93.

Bozkurt, B. (2018). Sosyal adalet liderliği ile yöneticiye bağlllık ve örgütsel vatandaşlık davranışları arasındaki ilişki (Yayımlanmamış doktora tezi). Gaziantep Üniversitesi, Gaziantep.

Brief, A. P. ve Motowidlo, S. J. (1986). Prosocial organizational behaviors. Academy of Management Review, 
11(4), 710-725.

Buluç, B. (2008). Ortaöğretim okullarında örgütsel sağlık ile örgütsel vatandaşlık davranışları arasındaki ilişki. Türk Ĕ̆itim Bilimleri Dergisi, 6(4), 571-602.

Buluç, B. (2015). The relationship between academic staff's perceptions of organizational justice and organizational citizenship behaviours. Studia Psychologica, 57(1), 49-62.

Büyüköztürk, Ş. (2006). Sosyal bilimler için veri analizi el kitabı. Ankara: PegemA Yayınları.

Cohen-Charash, Y. ve Spector, P. E. (2001). The role of justice in organizations: A meta analysis. Organizational Behavior and Human Decision Processes, 86(2), 278-321.

Colquitt, J. A. (2012). The Oxford handbook of organizational psychology. S. W. J. Kozlowski (Ed.). New York: Oxford University Press.

Colquitt, J. A., Greenberg, J. ve Zapata-Phelan, C. P. (2005). What is organizational justice? A historical overview. J. Greenberg ve J. A. Colquitt (Ed.). Handbook of organizational justice (s. 3-56) içinde. New Jersey: Lawrence Erlbaum Associates.

Crosby, F. (1976). A model of egoistical relative deprivation. Psychological Review, 83(2), 85-113. doi: 10.1037/0033-295X.83.2.85

Çağlayan, E. (2014). Öğretim elemanlarının örgütsel vatandaşlık davranışları ile örgütsel adalet algıları arasındaki ilişki. Kuram ve Uygulamada Ĕ̆itim Yönetimi, 20(4), 421-452.

Çavuş B. (2016). Öğretim elemanlarının örgütsel adalet algılarıla umutsuzluk düzeyleri arasındaki ilişki (Yayımlanmamış yüksek lisans tezi). Adnan Menderes Üniversitesi, Aydın.

Çelik, M. (2010). Öğretmen görüşlerine göre okul yöneticilerinin öğretimsel liderlik davranışı ile öğretmenlerin örgütsel vatandaşlık davranışlarının analizi (Yayımlanmamış yüksek lisans tezi). Selçuk Üniversitesi, Konya.

Çetin, Ş. (2011). Okul müdürlerinin liderliğinde müdür-öğretmen ilişkisinin öğretmenlerin örgütsel vatandaşlık davranışı üzerindeki etkisi (Yayımlanmamış doktora tezi). Gazi Üniversitesi, Ankara.

Çırak, S. (2013). İlköğretim okulu öğretmenlerinin örgütsel adalet algısı (Yayımlanmamış yüksek lisans tezi). Hacettepe Üniversitesi, Ankara.

Dağlı, E. (2015). İlköğretim okullarında müdürlerin kullandıkları etkileme taktiklerinin öğretmenlerin örgütsel vatandaşlık davranışları ve okul farkındalığı ile ilişkisi (Yayımlanmamış doktora tezi). Gazi Üniversitesi, Ankara.

Demirel, Y. (2009). Örgütsel adaletin yönetici-çalışan ilişkileri üzerine etkisi: Farklı sektör çalışanlarına yönelik bir araştırma. The Journal of Social Economic Research, 9(17), 137-154.

Demiröz, S. (2014). Öğretmenlerin örgütsel vatandaşlık davranışları, örgütsel imaj algıları ve öğrenci başarıları arasındaki ilişki (Yayımlanmamış doktora tezi). Hacettepe Üniversitesi, Ankara.

Dong, L. N. T. ve Phuong, N. N. D. (2018). Organizational justice, job satisfaction and organizational citizenship behavior in higher education institutions: A research proposition in Vietnam. Journal of Asian Finance, Economics and Business, 5(3), 113-119.

Dündar, H. (2012). Öğretmenlerin sahip olduğu değerler ile örgütsel vatandaşlık davranışları arasındaki ilişki. Erzincan Üniversitesi Ĕ̆itim Fakültesi Dergisi, 14 (2), 215-234.

Dündar, T. (2011). Öğretmenlerin örgütsel adalet algıları ile iş doyumu düzeyleri arasındaki ilişki (Yayımlanmamış yüksek lisans tezi). Yıldız Teknik Üniversitesi, İstanbul.

Ertürk, E. (2011). İlköğretim ve ortaöğretim okullarındaki örgütsel adalet algısı ile öğretmenlerin örgütsel adanmışlıkları arasındaki ilişki (Yayımlanmamış yüksek lisans tezi). Mehmet Akif Ersoy Üniversitesi, Burdur.

Folger, R. ve Cropanzano, R. (1998). Organizational justice and human resource management. London: SAGE 
Publications.

Ghazi, M., ve Jalali, S. (2017). The effects of organizational justice and job motivation on organizational citizenship behavior and its impact on taxpayers. Journal of History Culture and Art Research, 6(1), 136-151. doi: 10.7596/taksad.v6i1.710

Gilliland, S. W. (1994). Effects of procedural justice and distributive justice on reactions to a selection system. Journal of Applied Psychology, 79(5), 691-701.

Gök, D. (2014). İlkokul ve ortaokullarda görevli öğretmenlerin örgütsel adalet ve örgütsel bağlllk algılarının çeşitli değişkenler açısından incelenmesi (Şahinbey/Gaziantep örneği) (Yayımlanmamış yüksek lisans tezi). Gaziantep Üniversitesi, Gaziantep.

Gökmen, A. (2011). Illköğretim öğretmenlerinin örgütsel vatandaşlık davranışları ve bu davranışların okul etkililiği üzerindeki etkisine ilişkin algıları (Yayımlanmamış yüksek lisans tezi). Pamukkale Üniversitesi, Denizli.

Göksal, M. (2017). Sını öğretmenlerinin beş faktör kişilik özellikleri ile örgütsel vatandaşlık davranışları arasındaki ilişkinin incelenmesi (Yayımlanmamış yüksek lisans tezi). Kahramanmaraş Sütçü İmam Üniversitesi, Kahramanmaraş.

Greenberg, J. (1988). Equity and workplace status: A field experiment. Journal of Applied Psychology, 73(4), 606613.

Greenberg, J. (1990). Organizational justice: Yesterday, today and tomorrow. Journal ofManagement, 2(16), 399432.

Günbayı, İ., Dağll, E. ve Kalkan, F. (2013). İlköğretim okulu müdürlerinin destekleyici davranışları ile öğretmenlerin örgütsel vatandaşlık davranışları arasındaki ilişki. Kuram ve Uygulamada Ĕ̆itim Yönetimi, 19(4), 575-602.

Günce, S. (2013). Ilköğretim okullarında örgütsel adalet ile örgütsel bağgllık ilişkisi (Yayımlanmamış yüksek lisans tezi). Harran Üniversitesi, Şanlıurfa.

Gürbüz, S., ve Şahin, F. (2016). Sosyal bilimlerde araştırma yöntemleri. Ankara: Seçkin Yayıncllı.

Hair, J. F., Black, W. C., Babin, B. J., Anderson, R. E. ve Tatham, R. L. (2013). Multivariate data analysis. United States of America: Pearson Education Limited.

Harder, J. W. (1992). Play for pay: Effects of inequity in a pay-for performance context. Administrative Science Quarterly, 37(2) 321- 335.

Hoy, W. K. ve Miskel, C. G. (2012). Eğitim yönetimi: Teori, araştırma ve uygulama. Ankara: Nobel Akademik Yayıncilik.

İçerli, L. (2010). Örgütsel adalet: Kuramsal bir yaklaşım. Girişimcilik ve Kalkınma Dergisi, 5(1), 67-92.

Kahraman, Ü. (2014). Illkokullarda performans yönetimi uygulamaları ve öğretmenlerin örgütsel adalet algısı arasındaki ilişki (Yayımlanmamış yüksek lisans tezi). Uşak Üniversitesi, Uşak.

Karakaşoğlu, N. (2011). Eğitim yöneticilerinin yönetsel tarzları ile öğretmenlerin örgütsel vatandaşlık davranışları ve örgütsel tükenmişlik düzeyleri arasındaki ilişki (Yayımlanmamış yüksek lisans tezi). Uşak Üniversitesi, Uşak.

Karaköse, T., Altınkurt, Y. ve Yılmaz, K. (2009, Ekim). Örgütsel adaletin öğretmenlerin iş doyumu üzerine etkileri. 1-3 Ekim Uluslararası V. Balkan Eğitim ve Bilim Kongresi, Edirne.

Karakuş, M. (2008). İlköğretim okul yöneticilerinin ve öğretmenlerin duygusal zekâ yeterliklerinin, öğretmenlerin duygusal adanmışlık, örgütsel vatandaşlık ve iş doyumu düzeylerine etkisi (Yayımlanmamış doktora tezi). Fırat Üniversitesi, Elazığ.

Karriker, J. H. ve Williams, M. L. (2009). Organizational justice and organizational citizenship behavior: A 
mediated multifoci model. Journal of Management, 35 (1), 112-135. doi:10.1177/0149206307309265

Kılıç, E. (2013). Yatılı bölge ilköğretim okullarında örgütsel adalet: Sinop örneği. Journal of World of Turks, 5(2), 19-33.

Konovsky, M. A. (2000). Understanding procedural justice and its impact on business organizations. Journal of Management, 26(3), 489-511.

Köprülü, T. S. (2011). İlköğretim okullarındaki öğretmenlerin örgütsel vatandaşlık davranışları ile motivasyonlar arasındaki ilişki (Yayımlanmamış yüksek lisans tezi). Maltepe Üniversitesi, İstanbul.

Kubilay Baykal, Ö. (2013). Okul iklimi ile öğretmenlerin örgütsel vatandaşlık davranışı arasındaki ilişki üzerine bir araştırma (Yayımlanmamış yüksek lisans tezi). Yeditepe Üniversitesi, İstanbul.

Kurtulmuş, M. (2016). Farklılıkların yönetiminin öğretmenlerin örgütsel bağlllıklarına ve vatandaşlık davranışlarına etkisi. Pegem Eğitim ve Öğretim Dergisi, 6(3), 277-302.

Kuşci, E. (2014). Akademisyenlerin üniversitelerde örgütsel adalete ilişkin algıları (Yüzüncü Yıl Üniversitesi örneği) (Yayımlanmamış yüksek lisans tezi). Yüzüncü Yıl Üniversitesi, Van.

Laçinoğlu, Z. (2010). İlköğretim okulu öğretmenlerinin örgütsel adalet algıları ile bazı örgütsel davranışlar arasındaki ilişki (Yayımlanmamış yüksek lisans tezi). Sakarya Üniversitesi, Sakarya.

Leventhal, G. S. (1976). The distribution of rewards and resources in groups and organizations. Advances in Experimental SocialPsychology, 9, 91-131.

Leventhal, G. S., Karuza, J. ve Fry, W. R. (1980). Beyond fairness: A theory of allocation of preferences. G. Mikula (Ed.), Justice and Social interaction (s. 167-218) içinde. New York: SpringerVerlag Press.

Lunenburg, F. C. ve Ornstein, A. C. (2004). Educational administration: Concepts \& practices. Belmont, CA: Thomson Books/Cole.

Mohammad, J., Quoquab, F. ve Adnan, M. (2010). Organizational justice and organizational citizenship behavior in higher education institution. Global Business and Management Research: An International Journal, 2(1), 13-32.

Moorman, R. H. (1991). Relationship between organizational justice and organizational citizenship behaviors: Do fairness perceptions influence employee citizenship? Journal of Applied Psychology, 76(6), 845-855.

Niehoff, B. P. ve Moorman, R. H. (1993). Justice as a mediator of the relationship between methods of monitoring and organizational citizenship behaviour. Academy of Management Journal, 36(3), 527-556.

Organ, D. W. (1988). Organizational citizenship behaviour: The good soldier syndrome. Lexington: Lexington Books.

Organ, D. W. (1990). The motivational basis of organizational citizenship behaviour. Research in Organizational Behaviour, 12, 43-72.

Organ, D.W. ve Moorman, R. H. (1993). Fairness and organizational citizenship behavior: What are the connections. Social Justice Research, 6, 5-18.

Özdemir, A. (2010). İlköğretim okullarında algılanan yönetici desteğinin ve bireycilik-ortaklaşa davranış̧̧ılığın örgütsel vatandaşlık davranışı ile ilişkisi. Kuram ve Uygulamada Ĕ̆itim Yönetimi, 16(1), 93112.

Özdemir Demirel, G. (2012). Okul müdürlerinin güç kaynaklarını kullanma stilleri ve müdür desteğinin kurumsal vatandaşlık davranışıyla ilişsisi (Ankara ili örneği) (Yayımlanmamış yüksek lisans tezi). Gazi Üniversitesi, Ankara.

Özer, N., Demirtaş, H., Üstüner, M. ve Cömert, M. (2006). Ortaöğretim öğretmenlerinin örgütsel güven alg1ları. Ege Ĕ̆itim Dergisi, 7(1), 103-124.

Öztuğ, Ö. ve Baştaş, M. (2012). Öğretmenlerin örgütsel adalet konusundaki algılarının örgütsel bağl1lıkları 
üzerindeki etkisi. Hacettepe Üniversitesi Eğitim Fakültesi Dergisi, Özel Sayı 2, 125-133.

Öztürk Yaman, S. (2015). Ticaret meslek liselerinde çalışan meslek dersi öğretmenlerinin örgütsel vatandaşlı davranışları üzerine bir araştırma (Yayımlanmamış yüksek lisans tezi). Gazi Üniversitesi, Ankara.

Podsakoff, P. M. ve MacKenzie, S. B. (1989). A second generation measure of organizational citizenship behavior. (Unpublished manuscript). Indiana University, Bloomington.

Podsakoff, P. M. ve MacKenzie, S. B. (1997). Impact of organizational citizenship behavior on organizational performance: A review and suggestions for future research. Human Performance, 10(2), 133-151.

Podsakoff, P. M., Mackenzie, S. B., Moorman, R. H. ve Fetter, R. (1990). Transformational leader behaviors and their effects on followers' trust in leader, satisfaction and organizational citizenship behaviors. Leadership Quarterly, 1(2), 107-142.

Podsakoff, P. M., Mackenzie, S. B., Paine, J. B. ve Bachrach, D.G. (2000). Organizational citizenship behaviors: A critical review of the theoretical and empirical literature and suggestions for future research. Journal of Management, 26(3), 513-563.

Polat, S. (2007). Ortaöğretim öğretmenlerinin örgütsel adalet alglları, örgütsel güven düzeyleri ile örgütsel vatandaşlı davranışları arasındaki ilişki (Yayımlanmamış doktora tezi). Kocaeli Üniversitesi, Kocaeli.

Polat, S. ve Celep, C. (2008). Ortaöğretim öğretmenlerinin örgütsel adalet, örgütsel güven, örgütsel vatandaşlık davranışlarına ilişkin algıları. Kuram ve Uygulamada Eğitim Yönetimi, 14(2), 307-331.

Potuk, A. (2017). Mobbing davranışı, örgütsel adalet ve örgütsel sessizlik algıları arasındaki ilişki (Yayımlanmamış yüksek lisans tezi). Eskişehir Osmangazi Üniversitesi, Eskişehir.

Sezgin, F. (2005). Örgütsel vatandaşlık davranışları: Kavramsal bir çözümleme ve okul açısından bazı çıkarımlar. Gazi Eğitim Fakültesi Dergisi, 25(1), 317-339.

Sırıklıgil, E. (2015). Özel ve kamu sektöründe çalışan öğretmenlerde örgütsel vatandaşlık davranışı algısı (Yayımlanmamış yüksek lisans tezi). Dumlupınar Üniversitesi, Kütahya.

Sökmen, A., Şahal, S. ve Söylemez, M. (2015). Örgütsel adaletin örgütsel vatandaşlık davranışına etkisi: Savunma sektöründe bir araştırma. İşletme Araştırmaları Dergisi, 7(4), 66-91.

Söyük, S. (2007). Örgütsel adaletin iş tatmini üzerindeki etkisi ve İstanbul ilindeki özel hastanelerde çalışan hemşirelere yönelik bir çalışma (Yayımlanmamış doktora tezi). İstanbul Üniversitesi, İstanbul.

Şahin, R. ve Kavas, E. (2016). Örgütsel adalet ile örgütsel bağlılık arasındaki ilişkinin belirlenmesinde öğretmenlere yönelik bir araştırma: Bayat örneği. Süleyman Demirel Üniversitesi Vizyoner Dergisi, 7(14), 119140.

Şayir, G. (2015). Öğretmen algllarına göre okul müdürlerinin duygusal zekâ düzeyleri ile okul kültürünün örgütsel vatandaşlık davranışı üzerine etkisi (Yayımlanmamış yüksek lisans tezi). Atatürk Üniversitesi, Erzurum.

Tabancalı, E. ve Çakıroğlu, Z. K. (2017). Okul müdürlerinin etik liderlik davranışları ile öğretmenlerin örgütsel vatandaşlık davranışları arasındaki ilişki. Mersin Üniversitesi Eğitim Fakültesi Dergisi, 13(1), 392-417.

Tan, Ş. (2017). Meslek liselerinde örgütsel adaletin okul-sanayi işbirliğine etkisi ve örgütsel vatandaşlı̆̆ın aracı rolü: İstanbul ili örneği (Yayımlanmamış yüksek lisans tezi). Bahçeşehir Üniversitesi, İstanbul.

Thibaut, J. ve Walker, L. (1975). Procedural justice: A psychological analysis. Hillsdale, NJ: Erlbaum.

Uğurlu, C. T. ve Demir, A. (2016). Örgütsel vatandaşlık davranışının öncülü olarak okul yöneticilerinin kullandıkları güç kaynakları. Elektronik Sosyal Bilimler Dergisi, 15(56), 98-119.

Uludağ, O., Aktaş, İ. ve Özdoğaç Özgit, H. (2019). Eğitim çalışanlarının örgütsel adalet algılarının ve örgüt kültürünün bilgi paylaşımı üzerindeki etkileri: Örgüt kültürünün aracı rolü. Hacettepe Üniversitesi Ĕ̆itim Fakültesi Dergisi, 34(1), 160-181. doi: 10.16986/HUJE.2018037423 
Uslu, B. (2011). İlköğretim okulu öğretmenlerinin örgütsel vatandaşlı davranışlar (Manisa il örneği) (Yayımlanmamış yüksek lisans tezi). Ege Üniversitesi, İzmir.

Uysal, M. (2014). Genel liselerde görev yapan öğretmenlerin örgütsel adalet konusundaki algıları (Altındă̆ ilçesi örneği). Hacettepe Üniversitesi, Ankara.

Whitman, D. S., Caleo , S., Carpenter, N. C., Horner, M. T. ve Bernerth, J. B. (2012) Fairness at the collective level: A meta-analytic examination of the consequences and boundary conditions of organizational justice climate. Journal of Applied Psychology, 97(4), 776-791.

Yancı, F. (2011). Ortä̈ğretim okulu öğretmenlerinin duygusal zekâ düzeyleri ile örgütsel vatandaşlık davranışları arasındaki ilişki (Şanlıurfa ili örneği) (Yayımlanmamış yüksek lisans tezi). Harran Üniversitesi, Şanlıurfa.

Yaprak Kaya, Ö. (2015). Örgüt kültürü ve örgütsel vatandaşlık davranışı ilişkisi (Balıkesir ili merkez ilçe örneği) (Yayımlanmamış yüksek lisans tezi). Balıkesir Üniversitesi, Balıkesir.

Yenel, K. (2016). Illkokul yöneticilerinin dönüşümcü ve işlemci liderlik biçimleri ile öğretmenlerin örgütsel vatandaşlı ve örgütsel sessizlik davranışları arasındaki ilişki (Yayımlanmamış yüksek lisans tezi). Gazi Üniversitesi, Ankara.

Yıldırım, Ç. (2017). Lise öğretmenlerinin örgütsel vatandaşlık davranışlarının yordayıcısı olarak örgütsel sosyalleşme (Yayımlanmamış yüksek lisans tezi). İstanbul Sebahattin Zaim Üniversitesi, İstanbul.

Yıldırım, F. (2007). İş doyumu ile örgütsel adalet ilişkisi. Ankara Üniversitesi SBF Dergisi, 62(1), 253-278.

Yıldırım, G. (2015). Lise öğretmenlerinin örgütsel sinizm tutumlar ile örgütsel vatandaşlık davranışları arasındaki ilişki (Yayımlanmamış yüksek lisans tezi). Gazi Üniversitesi, Ankara.

Yıldız, H. (2015). Özel ilkokul ve ortaokul öğretmenlerinin örgütsel adalet algıları (Konya/Meram ilçesi örneği) (Yayımlanmamış yüksek lisans tezi). Mevlana Üniversitesi, Konya.

Yılmaz, K. (2012). İlköğretim okulu öğretmenlerinin iş doyumu düzeyleri ile örgütsel vatandaşlık davranışları arasındaki ilişki. Anadolu Journal of Educational Sciences International, 2(2), 1-14. 


\section{EXTENDED ABSTRACT}

\section{Introduction}

Whether the events and situations in the organization are fair or not affects the quality of employees' behaviours. In this context, social scientists have created a concept of "organizational justice" to explain the role of justice in the organization. Organizational justice is the employees' justice perceptions about the authorities.

Organizations need their employees to be eager to work beyond their job definition and to contribute to organizational effectiveness and development to continue their existence under changing circumstances (Sezgin, 2005). The behaviours involving willingness and more effort to meet this need are called organizational citizenship behaviours. Organizational citizenship behaviours are based on personal effort at the personal level, but they contribute to organizational performance at the collective level (Podsakoff and MacKenzie, 1997). Employees give different reactions cognitively and behaviourally according to their organizational justice perceptions (Bal, 2014). It is known that employees believing that they are treated fairly are more willing and that they perform organizational citizenship behaviours frequently (Atalay, 2005; Berber, 2010; Beugré, 2002; Greenberg, 1990; Moorman, 1991; Organ, 1990; Polat and Celep, 2008; Sezgin, 2005; Söyük, 2007; Uslu, 2011). In this context, organizational justice is essential for ensuring employees' personal satisfaction and making the organization function effectively.

The most important resource of the educational organization, which is a social construction based on collaboration, is the teacher. Teachers' perceptions and behaviours affect the functioning of the organization directly. Thus, knowing what organizational justice and organizational citizenship behaviour that contribute to personal and organizational effectiveness mean for educational organizations can facilitate the analysis of teachers' and principals' behaviours. The findings obtained by examining the correlation between these concepts are important in terms of contributing to educational organizations.

The aim of this research is to determine the correlation between organizational justice perceptions and organizational citizenship behaviours of teachers working in public primary and secondary schools in Pendik, Istanbul. The following questions are answered in the research:

1. What is the level of teachers' organizational justice perceptions?

2. What is the level of teachers' perceptions about organizational citizenship behaviours?

3. Is there a correlation between teachers' organizational justice perceptions and their perceptions about organizational citizenship behaviours?

4. To what extent does the level of teachers' perceptions about organizational justice and its subdimensions explain organizational citizenship?

\section{Method}

The research is designed as a correlational survey model. The population of the study consisted of 6983 teachers working in 138 different public schools in the 2017-2018 academic year in Pendik, Istanbul. The sample was determined with the convenience sampling method. The sample of the study was 721 teachers working in 36 different public schools in the same district. Data were collected with a personal information form, the "Organizational Justice Scale" and the "Organizational Citizenship Behaviour Scale". The data were analyzed with Pearson correlation and regression analysis.

\section{Results}

In the research findings, it was found that teachers' perceptions of organizational justice were at a "high" level. Accordingly, teachers found the management to be fair in the schools they worked for. This finding is consistent with many research results. According to the findings related to the sub-dimensions of organizational justice, a "high" level was determined in the interactive justice sub-dimension, while the distributional and operational justice sub-dimensions were found to be "medium". In this regard, teachers found the interpersonal behaviours (kindness, respect, sensitivity, etc.) of the administrators in their schools 
to be fairer than the decision-making process and the distribution of the resulting gains. In other words, teachers thought that the managers were sensitive to their personal needs, that they explained their decisions impartially to everyone without hiding their decisions, and that they were fair in their communication. On the other hand, they thought that the decision-making process and the resulting gains were not fair enough. A lack of professional competencies appropriate for the school administrators' position may have led to this result. In the findings, it was seen that the teachers exhibited their organizational citizenship behaviours at a "high" level. In other words, the teachers often exhibited voluntary behaviour that went beyond the officially defined role behaviour.

According to the analysis of the results, there was a poor positive correlation between teachers' organizational justice perceptions and organizational citizenship behaviours. A weak positive correlation was found between organizational justice and the sub-dimensions of organizational citizenship behaviours such as altruism, sportsmanship, conscientiousness, and civic virtue. Also, a weak positive correlation was found between organizational citizenship behaviours and the sub-dimensions of organizational justice such as distributive justice, procedural justice and interactional justice. It was found that organizational justice affected organizational citizenship behaviours significantly. Organizational justice predicted nearly $7 \%$ of organizational citizenship behaviours. All three sub-dimensions of organizational justice together predicted organizational citizenship behaviours significantly. All three sub-dimensions together explained $6 \%$ of total variance in organizational citizenship behaviours. When the relevance of the regression parameters was examined, it was found that procedural justice was an important precursor for organizational citizenship behaviours, but that distributive and interactional justice did not have an important effect.

\section{Conclusion}

Especially in educational organizations based on a centralized management approach, it is not possible to reach the targets only by performing certain duties. Collective actions that are not included in the job description and require extra effort and dedication are needed to maintain the functionality and survival of organizations. Fair educational environments and motivating leaders are needed to realize these unspecified and unidentified behaviours. Teachers who find their manager independent, who know that their gains are safe, and who have a say in organizational activities will be more willing to benefit the organization in cooperation, because fair management ensures that teachers see themselves as a valuable citizen of the organization. The behaviours exhibited in this context are personal choices, not the mandatory role behaviours which are clearly stated by the regulations. In order to display organizational citizenship behaviours that increase individual performance and organizational efficiency more frequently, administrators must create fair school climates. Better quality outputs can be presented to society with teamwork that emerges with a sense of belonging. 